\title{
HOW PLAIN IS LEGAL ENGLISH IN STATUTES?
}

\section{INTRODUCTION}

Clarity is one of the requirements a legislative text (law, statute) should meet. Manuals on legislative drafting describe different techniques helpful in achieving clarity. Using plain English is probably one of the most important techniques. Despite numerous recommendations to avoid archaic words, omit "shall", use simple syntactic structures and other methods traditionally promoted by the proponents of Plain English Movement it is argued the text of a statute is still often written in such a way that an ordinary reader, who it is normally aimed at, can hardly understand its contents without legal advice.

Has Plain English Campaign been really successful in making legislation clearer and thus more understandable? This article analyzes whether any changes have taken place in legal English used in British statutes.

In the United Kingdom an attempt to implement Plain English principles was made within the Tax Law Rewrite project. ${ }^{1}$ In 2006 the Office of the Scottish Parliamentary Counsel prepared a booklet on plain language in legislation. ${ }^{2}$ In 2008 the Office of the Parliamentary Counsel responsible for drafting British statutes adopted "Recommendations and Policies on Drafting Matters"3 as well as some Papers on clarity in drafting, gender-neutral drafting and modal verbs in laws. ${ }^{4}$ The dates mentioned explain the choice of material for research: Acts of Parliament dated 2006-2012 to see if the statutes have become plainer since official documents were adopted.

\section{ANALYSIS}

No doubt "the sheer volume of works commenting on plain language and legislation can be overwhelming" (Plain Language and Legislation ${ }^{5}$ ). To put it short, for a

\footnotetext{
* Author's address: Department of translation theory and intercultural communication, Voronezh State University, Universitetskaya pl. 1, Voronezh, Russia, 394006. E-mail: borisova_la@rgph.vsu.ru

1 For more information see www.hmrc.gov.uk/rewrite/wayforward/tlra1.htm

2 See http://www.scotland.gov.uk/Publications/2006/02/17093804/0

3 Seehttp://www.docstoc.com/docs/52267864/OFFICE-OF-THE-PARLIAMENTARY-COUNSELRECOMMENDATIONS-AND-POLICIES-ON

4 See http://www.cabinetoffice.gov.uk/media/190016/clarity\%20paper\%20with\%20hyperlinks.pdf, http:/www.cabinetoffice.gov.uk/media/190076/shall.pdf, www.cabinetoffice.gov.uk/media/190046/ gnd_lion.pdf

5 http://www.scotland.gov.uk/Publications/2006/02/17093804/0
} 
statute to be clear and thus more understandable, firstly, it must be well-organized and structured and, secondly, it must be written in a good language with clear vocabulary and grammar.

Clear organization and structure presupposes the division of the legislative text into parts and chapters, the use of headings and subheadings, paragraphing, clause length, the use of typographical means, the layout of the text, etc. It is necessary to note that these requirements are mostly satisfied by legislative drafters of Great Britain that is why we will not discuss them in detail here. The only point we would like to pay special attention to is the use of overview provisions. As the Office of the Parliamentary Counsel states in its recommendations

A clause at the beginning of a Bill, or of a Part or Chapter, explaining what is to follow may help the reader to navigate round a larger Bill where the table of contents is too long to give a clear picture (Clarity in Drafting ${ }^{6}$ ).

Overview provisions are still rare in legislation. For example, they can be found in Income Tax Act 2007, Corporation Act 2009, Finance Act 2012. Though these Acts are not the only ones that are long enough they are the only ones that contain such provisions.

Any statute contains definitions. Putting them in the right place of the text and organizing them effectively improves readability of a statute. So it is advisable to include a general interpretation section with a comprehensive list of all terms defined in the Act. Our study shows that any British statute contains a special section called either "Interpretation" or "Definitions" or "Meaning of..." with a list of terms and their explanation. If the list is pretty long there may be a special section called "Index" in the form of a table with an alphabetical list of terms in the left-hand column and the provisions which contain the definitions in the right-hand column. Traditionally interpretation sections can be placed anywhere in the statute: at the beginning of the statute, in the middle, right where the defined term is used or at the end of the law. They can also be included in a schedule to the statute. The Office of the Scottish Parliamentary Counsel suggests that "[i]t can be helpful to define a term near to where it is first used (with any general interpretation provision referring back to the principal definition)" (Plain Language and Legislation $\left.{ }^{7}\right)$. As for interpretation sections, they normally constitute one of the final provisions of a statute and it is recommended that they be placed at the end of the text before schedules, if any. It seems that the Index section may be appropriate in a schedule to the Act because schedules are usually used by drafters to present the information in a more systematic way. Besides, once a reference to the schedule with the index of terms is made, it makes the navigation of the statute easier.

Examples of properly organized definition sections can be found in Serious Crime Act 2007, Counter-Terrorism Act 2008, Finance Act 2012, Civil Aviation Act 2012.

6 http://www.cabinetoffice.gov.uk/media/190016/clarity\%20paper\%20with\%20hyperlinks.pdf

7 http://www.scotland.gov.uk/Publications/2006/02/17093804/0 


\section{Interpretation: Part 1}

In this Part-

"act" and "conduct" include omissions and statements;

"country" includes territory;

"modifications" includes additions and omissions (and "modify" is to be read accordingly);

"the public" includes a section of the public or a particular member of the public.

\section{Index of defined expressions: Part 1}

In this Part, the expressions listed in the left-hand column have the meaning given by, or are to be interpreted in accordance with, the provisions listed in the right-hand column.

\begin{tabular}{|l|l|}
\hline Expression & Provision \\
\hline act & section 42 \\
\hline committed a serious offense & section $4(1)$ \\
\hline conduct & section 42 \\
\hline country & section 42 \\
\hline
\end{tabular}

(Serious Crime Act 2007)

Thus we can make a conclusion that definitions are not put chaotically but rather are systematized according to certain principles.

A lot of criticism is expressed in connection with references and cross-references used in British statutes.

There is no need to include words such as "of this Act / Part / section" in cross-references to the same Act, Part or section unless clarity will be compromised by other references in the provision. Similarly, there is no need to state whether a provision being referred to is above or below the crossreference (Plain Language and Legislation ${ }^{8}$ ).

However, the tradition to use phrases like "of this Act / Part / section, to this Act, subject to, under (section ...)" is strong enough. A way to improve references is to use signposts, e.g. the phrase "see section..." in brackets. We have counted that such a signpost was used in 31\% of the Acts passed in 2006 whereas in 2009 and 2012 already up to $60 \%$ of the Acts contained this phrase.

8 http://www.scotland.gov.uk/Publications/2006/02/17093804/0 
As far as the language aspects are concerned, Plain English Movement proponents often emphasize the importance of avoiding archaic words, Latin words and neologisms, of using Present Tense, Active Voice and modals like "must" instead of "shall", etc.

We would start with providing a more detailed analysis of the two most heavily criticized linguistic features of statutes: archaic words and the modal "shall".

All Plain English proponents suggest avoiding archaic words. In its booklet "Plain Language and Legislation" the Office of the Scottish Parliamentary Counsel enumerates legal words that "have served their time" (Plain Language and Legislation"). To these belong "aforesaid", "forthwith", "foregoing", "hereinafter", "notwithstanding", "said", "therein" and "whatsoever". We would also add to this list the words like "hereby", "thereafter", "thereof", "thereby", "thereunder", "thereto", "nonetheless".

To decide if law drafters have taken into consideration this piece of advice let us compare how many times each word was used in the British Acts of Parliament in 2006, 2009 and 2012. The data can be seen in the following table:

\begin{tabular}{|l|l|l|l|}
\hline Word & $\mathbf{2 0 0 6}$ & $\mathbf{2 0 0 9}$ & $\mathbf{2 0 1 2}$ \\
\hline aforesaid & 0 & 0 & 0 \\
\hline foregoing & 0 & 1 & 0 \\
\hline forthwith & 20 & 2 & 2 \\
\hline hereby & 10 & 3 & 0 \\
\hline hereinafter & 0 & 0 & 0 \\
\hline nonetheless & 0 & 1 & 2 \\
\hline notwithstanding & 60 & 9 & 8 \\
\hline said & 7 & 6 & 0 \\
\hline thereafter & 4 & 1 & 1 \\
\hline thereby & 8 & 0 & 0 \\
\hline therein & 1 & 0 & 0 \\
\hline thereof & 1 & 7 & 1 \\
\hline thereto & 2 & 4 & 0 \\
\hline thereunder & 0 & 0 & 0 \\
\hline whatsoever & 6 & 4 & 1 \\
\hline
\end{tabular}

Table 1: The use of archaic words

For our analysis to be more accurate we have excluded the cases when the archaic words were quoted in other Acts to be omitted or substituted.

9 http://www.scotland.gov.uk/Publications/2006/02/17093804/0 
One may notice from the table that while some archaic words are not actually used by law drafters ("aforesaid", "hereinafter", "thereunder"), others are used occasionally ("foregoing", "nonetheless", "therein", "thereof", "thereto") and still others have come to be used less frequently ("forthwith", "hereby", "notwithstanding", "said", "thereafter", "thereby", "whatsoever"). The most radical changes, in our view, are connected with the use of "forthwith", "hereby", "notwithstanding". For the data to be more accurate we found out that in 2006 British Parliament passed 51 public acts whereas in 2009 and 2012 there were 27 and 23 of them respectively. Though in 2006 there were nearly twice as many Acts as in the following years we do not think that the data provided cannot be illustrative enough.

The modal verb most criticized by the proponents of Plain English movement is definitely "shall". First of all, the proponents argue that "shall" should be replaced with "must" in cases when a duty or an obligation is imposed. Let us consider one of the most typical phrases used in British statutes with the subject of the sentence being "the Secretary of State". In other words, this legislative provision is normally about some duty that the Act imposes on this high official. We have analyzed how often the legislative drafters use "shall" and "must" to express obligation. The results can be seen in the following table.

\begin{tabular}{|l|l|l|}
\cline { 2 - 3 } \multicolumn{1}{c|}{} & the Secretary of State shall & the Secretary of State must \\
\hline 2006 & $\begin{array}{l}\text { 17 Acts (34\% of the Acts passed } \\
\text { within this year) (117 examples) }\end{array}$ & $\begin{array}{l}\text { 24 Acts (47\% of the Acts passed } \\
\text { within this year) (294 examples) }\end{array}$ \\
\hline 2009 & $\begin{array}{l}\text { 5 Acts (19\% of the Acts passed within } \\
\text { this year) (12 examples) }\end{array}$ & $\begin{array}{l}\text { 15 Acts (56\% of the Acts passed } \\
\text { within this year) (252 examples) }\end{array}$ \\
\hline $\begin{array}{l}\text { 3 Acts (13\% of the Acts passed within } \\
\text { this year) (3 examples) }\end{array}$ & $\begin{array}{l}\text { 11 Acts (48\% of the Acts passed } \\
\text { within this year) (268 examples) }\end{array}$ \\
\hline
\end{tabular}

Table 2: The use of "shall" and "must"

Thus, the statistics show firstly, that proportionally "must" is used more frequently than "shall" at one given time period and secondly, that within a period of six years the use of "shall" has fallen drastically. It is necessary to note that even of the three cases mentioned in connection with 2012 Acts two concerned the context when a new Act made amendments to some earlier Acts and so the drafter may have preferred to follow the then more traditional use of "shall".

We have counted that all in all "shall" was used in 2012 Acts 125 times. Almost a half of this usage was in Welfare Reform Act 2012. In the other Acts in 99\% of cases "shall" was used in the provisions modifying the ones in the earlier Acts dated, for example, 1982, 1991, 2001 etc. Even in the Welfare Reform Act 2012 itself about 50\% of "shall" usage is in amendments to other Acts. So we can conclude that changes in legislative drafting as far as expressing obligation is concerned are taking place and not at a slow speed as it seems. 
Another "most criticised usage of "shall" is when it is used for declaratory or descriptive purposes" (Plain Language and Legislation ${ }^{10}$ ). We distinguish between at least ten types of legislative provisions where "shall" is used in such functions depending on the theme of the provision.

1. Provisions about establishing some legal body or some official post etc.

There shall be a body corporate known as the Homes and Communities Agency ("the HCA") (Housing and Regeneration Act 2008).

None of such provisions in 2012 Acts contains "shall" in this context. It is replaced with Present Simple of "to be".

There is to be a body corporate known as the Disclosure and Barring Service (Protection of Freedoms Act 2012).

2. Provisions about the scope of application of the Act or its sections.

Part 1 of the 1986 Act shall apply to a proposal made by a bank liquidator, with the following modifications (Banking Act 2009).

None of such provisions in 2012 Acts contains "shall" in this context. It is replaced with Present Simple.

This Act applies only in relation to consumer insurance contracts entered into [...] (Consumer Insurance (Disclosure and Representations) Act 2012).

3. Provisions about a legal status or legal consequences.

Any person who suffers loss by the extinguishment of any right of way under this section shall be entitled to be compensated by the nominated undertaker (Crossrail Act 2008).

An individual who contravenes a requirement imposed on him by or under this section shall be liable to a civil penalty not exceeding £1,000 (Identity Cards Act 2006).

In 2012 Acts legislative drafters use Present Simple in all such contexts.

For the purposes of this Act a person is entitled to engage in or to be in any employment if [...] (Welfare Reform Act 2012).

A person who commits an offence under this section is liable on summary conviction pursuant to subsection (2) to imprisonment for a term not exceeding

10 http://www.scotland.gov.uk/Publications/2006/02/17093804/0 
the applicable term, or a fine not exceeding level 5 on the standard scale, or both (Welfare Reform Act 2012).

4. Provisions about making amendments.

The Justice (Northern Ireland) Act 2002 (c. 26) shall be amended as follows (Justice and Security (Northern Ireland) Act 2007).

In all such provisions of 2012 Acts "shall" is replaced with Present Simple.

Schedule 1 to the Licensing Act 2003 (c. 17) is amended as follows (Live Music Act 2012).

5. Provisions about repealing earlier Acts or their sections.

Section 147 of the Inclosure Act 1845 (c. 118) (power to exchange common land for other land) shall cease to have effect (Commons Act 2006).

In 2012 Acts legislative drafters use Present Simple in all such contexts.

Sections 357EA to 357EC cease to have effect [...] (Finance Act 2012).

6. Provisions referring to a schedule to the Act.

Schedule 27 to this Act (emergency fisheries byelaws) shall have effect (Marine and Coastal Access Act 2009).

None of such provisions in 2012 Acts contains "shall" in this context. It is replaced with Present Simple.

Schedule 6 (which makes transitional provision in connection with this Part) has effect (Health and Social Care Act 2012).

7. Financial provisions.

There shall be paid out of money provided by Parliament [...] (Autism Act 2009).

Only in two Acts passed in 2012 legislative drafters use "shall" (Scotland Act 2012, Welfare Reform Act 2012) while in the others they replace it with the modal expression "to be to".

There is to be paid out of money provided by Parliament any expenditure incurred in consequence of this Act by a Minister of the Crown, 
government department or other public authority (Public Services (Social Value) Act 2012).

8. Provisions about orders and regulations that can be issued under the statute.

Rules under this section shall be made by statutory instrument $[\ldots]$ (Companies Act 2006).

None of such provisions in 2012 Acts contains "shall" in this context. It is replaced either with "must" or "to be to".

Regulations under section 96 must be made by statutory instrument (Welfare Reform Act 2012).

Regulations under this section are to be made by statutory instrument (Legal Aid, Sentencing and Punishment of Offenders Act 2012).

\section{Extent provisions.}

This Act shall extend to England and Wales only (Compensation Act 2006).

In all such provisions of 2012 Acts "shall" is replaced with Present Simple.

Apart from the provisions listed in subsection (7), this Act extends to England and Wales, Scotland and Northern Ireland (Consumer Insurance (Disclosure and Representations) Act 2012).

10. Commencement provisions.

The remaining provisions of this Act shall come into force on such day as the Secretary of State may appoint by order made by statutory instrument (NHS Redress Act 2006).

Only Live Music Act 2012 contains "shall" in this context while in the other Acts Present Simple is used instead.

This Act comes into force on such day as the Secretary of State may by order made by statutory instrument appoint (Domestic Violence, Crime and Victims (Amendment) Act 2012).

So our analysis shows that in 2012 "shall" practically fell out of use in legislative drafting and was replaced with "must" for obligations and Present Simple for declarations.

Among linguistic features that make statutes plainer and more comprehensible is the use of Active Voice instead of Passive Voice. Our study shows that legislative drafters 
use Active Voice more often than Passive. The latter is preserved for gender-neutral drafting, for example,

Where the power under subsection (4) is exercised-

(a) the person exercising the power must notify the Secretary of State of what has been done and of the reasons for doing it [...] (Planning Act 2008).

Passive Voice is also used in certain types of provisions like short title, repeals and amendments:

This Act may be cited as the Crossrail Act 2008 (Crossrail Act 2008).

The Housing and Regeneration Act 2008 (c. 17) is amended as follows.

The enactments and instruments set out in Schedule 4 are repealed or revoked to the extent shown in that Schedule (Consumer Credit Act 2006).

One of the syntactic features of British statutes is the use of cumulative or alternative paragraphs, with "and" or "or" appearing at the end of the penultimate paragraph. "Where provisions are divided into numerous paragraphs a reader may take some time to reach the conjunctive which follows the penultimate paragraph" (Plain Language and Legislation ${ }^{11}$. Besides,

such a sequence of paragraphs can be awkward to amend later. If what was the penultimate paragraph ceases to be in that position, you will have to consider shifting the position of the "and" or the "or" so that it is at the end of the new penultimate paragraph (Clarity in Drafting ${ }^{12}$ ).

So it is suggested to use expressions like "each / any / all / either / both of the following". Though statistically the conjunctions "and" and "or" for connecting paragraphs prevail (over $80 \%$ of Acts), we have noticed that they are more commonly used when there are only two paragraphs to connect whereas three or more paragraphs are more likely to be connected with the expression with "of the following":

Regulations under this section may, in particular, specify a procedure that requires any or all of the following -

(a) an application to be made in a particular form;

(b) information to be supplied in support of an application;

(c) a fee to be paid in respect of an application (Tribunals, Courts and Enforcement Act 2007).

11 http://www.scotland.gov.uk/Publications/2006/02/17093804/0

12 http://www.cabinetoffice.gov.uk/media/190016/clarity\%20paper\%20with\%20hyperlinks.pdf 
Criticism is also expressed in connection with the use of "where" in subordinate clauses. It is considered that "if" or "when" would be more appropriate in this position, though it is admitted these words cannot always be used interchangeably.

Subsection (2) applies where, on a trial on indictment with a jury, any evidence has been given by a witness at a time when a witness anonymity order applied to the witness (Criminal Evidence (Witness Anonymity) Act 2008).

Our study shows that little has changed in this respect. "Where" is still a common practice in legislative drafting.

To sum up the changes in the language of British statutes we may state that the most obvious change concerns archaic words and the modal "shall" which practically ceased to be used in 2012. Active Voice and Present Tense have become a convention of legislative drafting. On the other hand, the tradition of using back-references and cross-references is strong enough and changes, if any, are slow.

Further research in this area may be connected with the analysis of the syntactic characteristics of a British statute. For example, one feature is that a subsection (or section if not divided into subsections) should consist of one sentence which results in the length of a sentence exceeding a hundred words. However, one can already find subsections split into two, sometimes even three sentences. Another point is the use of complex sentences with different types of subordinate clauses. The conjunction "where" traditionally used in a statute to express a condition attracts criticism because its function is similar to the conjunction "if" and in most cases one can hardly draw a line between the two in the context. Finally, the structure of a legislative sentence may be discussed. Drafters are recommended to avoid using sandwich clauses when there are some qualifications inserted between the main clause and the subordinate one. That impedes clarity and confuses the reader. So, the influence of the Plain English Campaign on the syntax of British statutes can become the subject of further research.

\section{CONCLUSION}

Plain English Campaign whose main purpose is to make documents clear and understandable for ordinary readers became extremely popular in the XXI century. This Campaign places special emphasis on legal texts encouraging the drafters to make them comprehensible with the help of different techniques. Legislative texts are specific in that the prospective readers are different. On the one hand, these are the people whose interests and rights the Act is aimed to protect and these people may belong to absolutely different social groups. On the other hand, laws are traditionally read by lawyers and judges. "Designing legislation primarily for those who may be involved in litigating on its terms may however reduce the chance of it being understood by the persons it will affect directly" (Plain Language and 
Legislation $^{13}$ ). Thus a legislative drafter has to strike a balance between the two different categories of readers.

Plain English Campaign is aimed at achieving clarity. However, one must not forget that a law must satisfy other requirements such as certainty and precision. Besides, laws are normally devoted to complex relations, which are not easy to understand, explain and regulate. That is why using plain language should not be understood as simplifying the language so as it can be understood by a person with any background and any education but rather employing such linguistic, textual and other means that will help the reader to grasp the contents of the message more easily.

Finally, one must not forget that the traditions of legislative drafting are different in different countries. They are especially different if the countries have different legal systems, for example, common law and continental law. So the way laws are drafted depends much on the history and culture of the country.

The United Kingdom is a common-law country. The basic principles of legislative drafting were formulated long ago. However, at any period there were attempts to make legislation up to date, to reform it so as to satisfy the needs of those who it is aimed at. Drafters are aware of the necessary changes but the speed of reforms may not satisfy everybody and may not be that noticeable. Plain English Campaign has gradually been affecting legislative drafting in Great Britain, but it will definitely take years (probably, decades) to make changes more obvious.

\section{Primary sources}

UK parliament - bills and legislation. 27 May 2013. http://www.parliament.uk/ business/bills-and-legislation/.

\section{References}

Clarity in drafting: principles and techniques: Drafting Techniques Group Paper 21 (final). 10 June 2013. http://www.cabinetoffice.gov.uk/media/190016/clarity\%20 paper\%20with\%20hyperlinks.pdf.

Gender-neutral drafting techniques: Drafting Techniques Group Paper 23 (final). 15 May 2013. http://www.cabinetoffice.gov.uk/media/190043/gnd.pdf.

Plain language and legislation. Office of the Scottish Parliamentary Counsel. 10 May 2013. http://www.scotland.gov.uk/Publications/2006/02/17093804/0.

Recommendations and policies on drafting matters. Office of the Parliamentary Counsel. 01 June 2013. http://www.docstoc.com/docs/52267864/OFFICE-OF-THEPARLIAMENTARY-COUNSEL-RECOMMENDATIONS-AND-POLICIES-ON.

Shall: Drafting Techniques Group Paper 19 (final). 10 June 2009. http://www.cabinetoffice.gov.uk/media/190076/shall.pdf.

Tax law rewrite: the way forward. 27 May 2013. http://www.hmrc.gov.uk/rewrite/wayforward/menu.htm.

13 http://www.scotland.gov.uk/Publications/2006/02/17093804/0 


\section{Abstract \\ HOW PLAIN IS LEGAL ENGLISH IN STATUTES?}

This article analyzes whether Plain English Campaign has influenced the language of British statutes. The author enumerates some requirements plain English in legislation should satisfy and compares to what extent, if any, the drafters of legislative texts have managed to satisfy these requirements. Special attention is paid to the most criticized features of statutes such as archaic words and the modal "shall". Some other aspects analyzed in the article are the use of Voice, Tenses, syntax and organization of British statutes. The author provides examples illustrating the points stated, outlines a perspective for further research and comments on some difficulties Plain English Campaign may face in the UK as far as the legislative texts are concerned.

Keywords: Plain English Campaign, statute, legal English.

\section{Povzetek \\ KAKO JASNA JE PRAVNA ANGLEŠČINA V ZAKONSKIH BESEDILIH?}

Avtorica preučuje, ali je tako imenovana Plain English Campaign vplivala na jezik britanskih zakonskih besedil. Pri tem našteje nekaj zahtev, ki bi jim morala v zakonodaji zadostiti »preprosta « angleščina, in primerjalno ugotavlja, v kolikšni meri - in ali sploh - avtorji zakonodajnih besedil te napotke upoštevajo. Posebno pozornost namenja najspornejšim posebnostim zakonov, kot sta raba arhaičnih besed in modalnega glagola shall. V prispevku se dotakne tudi glagolskega načina, rabe časov, skladnje in organizacije britanskih zakonskih besedil. V ponazoritev navaja različne primere, nakazuje poti nadaljnjih raziskav in oriše nekaj težav, na katere bo Plain English Campaign zelo verjetno naletela pri obravnavi zakonskih besedil v Veliki Britaniji.

Ključne besede: Plain English Campaign, zakonsko besedilo, pravna angleščina. 